\title{
PERAN PEREMPUAN DALAM TRADISI UPACARA BERSIH DESA (STUDI KASUS DI DESA KIRINGAN KECAMATAN TAKERAN KABUPATEN MAGETAN)
}

\author{
Anita Setyowati \& Muhammad Hanif*
}

\begin{abstract}
Abstrak
Indonesia merupakan sebuah negara yang kaya akan adat istiadat atau tradisi. Salah satu tradisi yang masih dilestarikan oleh masyarakat adalah tradisi upacara bersih desa. Di Desa Kiringan,Kecamatan Takeran, Kabupaten Magetan tradisi bersih desa rutin digelar setahun sekali. Sebuah tradisi yang merupakan wujud syukur masyarakat terhadap hasil panen, serta bertujuan untuk membersihkan desa dari segala balak atau bencana. Tradisi upacara bersih desa merupakan sebuah tradisi yang tak bisa dilepaskan dari peran kaum perempuan dalam pelaksanaannya. Anggapan bahwa perempuan itu irrasional atau emosional sehingga perempuan tidak bisa tampil sebagai pemimpin, berakibat munculnya sikap yang menempatkan perempuan pada posisi yang tidak penting. Tetapi anggapan tersebut terbantahkan. Dengan kenyataan bahwa dalam tradisi upacara bersih desa peran kaum perempuan sangat penting, sehingga keberadaan mereka tidak dapat dipandang sebelah mata. Dalam budaya dan tradisi tertentu, perempuan mendapatkan tempat yang terhormat di masyarakat Indonesia.

Penelitian ini bertujuan mengungkap peran perempuan dalam tradisi upacara bersih desa. Penelitian ini dilakukan dilakukan di Desa Kiringan Kecamatan Takeran Kabupaten Magetan. Jenis penelitian deskriptif kualitatif. Data diperoleh dari sumber primer dan sekunder berupa keterangan atau fakta dari informan dan peristiwa atau aktivitas serta dokumen dan arsip lain yang relevan. Analisis data dengan analisis interaktif.

Hasil penelitian menunjukkan bahwa peran perempuan dalam tradisi upacara bersih desa di Desa Kiringan adalah sebagai penyedia atau pembuat uborampe dan sebagai tledhek atau penari dalam kesenian Tayub.
\end{abstract}

Kata kunci: perempuan, tradisi, bersih desa

\section{Pendahuluan}

Keragaman budaya adalah keniscayaan yang ada di bumi Indonesia. Kebudayaan adalah gagasan, tindakan dan hasil karya manusia yang diperoleh dengan cara belajar (Koentjaraningrat, 2009: 144). Keragaman budaya di Indonesia adalah sesuatu yang tidak dapat dipungkiri keberadaannya. Selain kebudayaan kelompok suku bangsa, masyarakat Indonesia juga terdiri dari berbagai kebudayaan daerah bersifat kewilayahan yang merupakan pertemuan dari berbagai kebudayaan kelompok suku bangsa yang ada di daerah tersebut.

Sebagai bangsa yang majemuk, Indonesia memiliki dua macam sistem budaya yang sama-sama harus dipelihara dan dikembangkan, yakni sistem budaya nasional dan sistem budaya etnik lokal. Sistem budaya nasional adalah sesuatu yang relatif baru dan sedang berada dalam proses pembentukannya. Sistem ini berlaku

* Anita Setyowati adalah alumni Pendidikan Sejarah IKIP PGRI MADIUN

* Muhammad Hanif adalah Dosen Pendidikan Sejarah IKIP PGRI MADIUN 
secara umum untuk seluruh bangsa Indonesia, tetapi sekaligus berada di luar ikatan budaya etnik lokal (Abraham Nurcahyo, Soebijantoro, M. Hanif, Yudi Hartono, 2009: 39).

Pertemuan-pertemuan dengan kebudayaan luar juga mempengaruhi proses asimilasi kebudayaan yang ada di Indonesia sehingga menambah ragamnya jenis kebudayaan yang ada di Indonesia. Kemudian juga berkembang dan meluasnya agama-agama besar di Indonesia turut mendukung perkembangan kebudayaan Indonesia sehingga mencerminkan kebudayaan agama tertentu.

Aset budaya yang tersebar di seluruh wilayah Indonesia memberi nuansa keanekaragaman corak adat dan tradisi. Tradisi sendiri lahir dari kebiasaan-kebiasaan yang dilakukan oleh anggota masyarakat terdahulu yang kemudian ditirukan dan dilakukan oleh generasi berikutnya. Proses peniruan tersebut berlangsung dalam jangka waktu yang cukup lama. Masyarakat meyakini dan mempercayai keberadaannya. Bahkan tak jarang juga bahwa tradisi tersebut pada akhirnya menjadi sebuah keharusan yang wajib dipenuhi oleh masyarakat yang bersangkutan. Seiring dengan perkembangan peradaban dan kebudayaan manusia, berbagai macam bentuknya pun masih tetap hidup terpelihara serta dijalani oleh masyarakat sampai dengan saat sekarang ini. Banyak mitologi yang mengutamakan kepentingan umum atau masyarakatnya dari pada kepentingan pribadinya, sehingga dalam berbagai kegiatan selalu melibatkan banyak orang (Budiono Herusatoto, 2008: 130).

Dalam berbagai kesempatan, upacara tradisional dilaksanakan dengan melibatkan banyak orang. Seperti halnya dengan tradisi upacara bersih desa di Desa Kiringan Kecamatan Takeran Kabupaten Magetan yang selalu rutin digelar setahun sekali. Dalam mewarnai dalam kehiduan masyarakat tradisional. demikian pula halnya pada masyarakat Jawa yang dikenal dengan keyakinan kejawennya. Kejawen merupakan sebuah kepercayaan yang dianut oleh suku Jawa dan suku bangsa lainnya yang menetap di Jawa. Budaya kejawen ini merupakan budaya yang unik dalam masyarakat Jawa. Dikatakan unik karena kejawen memiliki tradisi mistik yang berbeda dengan daerah lainnya.

Salah satu contoh budaya kejawen yang tak asing dikenal oleh masyarakat adalah upacara tradisional Jawa. Upacara tradisional Jawa dilakukan demi mencapai ketentraman hidup lahir batin. Dengan mengadakan upacara tradisional itu, orang Jawa memenuhi kebutuhan spiritualnya. Kehidupan rohani orang Jawa memang bersumber dari ajaran agama yang diberi hiasan budaya lokal yang berbau magis atau ghaib. Oleh karena itu, orientasi kehidupan keberagaman orang Jawa senantiasa memperhatikan nilai-nilai luhur yang telah diwariskan oleh nenek moyangnya. Di samping itu, upacara tradisonal Jawa dilakukan dengan tujuan memperoleh solidaritas sosial. Upacara tradisional juga menumbuhkan etos kerja kolektif yang tercemin dalam ungkapan gotong royong.

Sikap hidup orang Jawa yang etis, estetis dan spiritualis, serta taat kepada adat istiadat warisan nenek moyangnya selalu pelaksanaan tradisi bersih desa inipun selalu melibatkan banyak warga desa setempat Sebuah tradisi yang merupakan wujud syukur masyarakat terhadap hasil panen, serta bertujuan untuk membersihkan desa dari segala balak atau bencana.

Masyarakat Desa Kiringan mempercayai bahwa lingkungan hidup perlu dilestarikan dengan cara ritual atau tradisi keagamaan yang mengandung nilai kearifan lokal. 
Masyarakat percaya bahwa apabila tradisi tersebut tidak dilaksanakan, desa mereka akan mendapatkan balak atau bencana. Rangkaian dari tradisi upacara bersih desa di Desa Kiringan berupa kegiatan membersihkan makam, selamatan yang dilakukan di Punden (makam sesepuh desa), sambutan dari perangkat desa, dan ditutup dengan acara langen beksan berupa kesenian tari Gambyong atau Tayub pada malam harinya.

Tradisi upacara bersih desa merupakan sebuah tradisi yang membutuhkan banyak hal yang perlu untuk dipersiapkan. Dalam kegiatan persiapan tersebut tidak hanya dilakukan oleh kaum laki-laki saja, tetapi kaum perempuan pun juga ikut melakukan banyak persiapan. Misalnya berkaitan dengan dengan uborampe. Uborampe adalah perlengkapan yang diperlukan/digunakan dalam acara selamatan dalam tradisi upacara bersih desa maupun dalam tradisi lainnya. Uborampe ini ada banyak macamnya, seperti nasi kuning, ingkung, dan kembang, dan lain sebagainya. Dalam hal ini, para kaum perempuan yang bertugas untuk memenuhinya karena kaum perempuan dianggap sebagai seseorang yang lebih ahli atau mampu dalam hal masak memasak atau yang berkaitan dengan masalah dapur lainnya. Selain berperan sebagai pembuat atau penyedia uborampe, ada beberapa peran atau tugas lain yang juga dilakukan oleh kaum perempuan.

Tradisi upacara bersih desa merupakan sebuah tradisi yang tak bisa dilepaskan dari peran kaum perempuan dalam pelaksanaannya. Bahkan dapat dikatakan bahwa tanpa keberadaan dan peran serta dari perempuan, tradisi upacara bersih desa ini tidak akan terlaksana. Jika terlaksana, rasanya tidak akan lengkap tanpa turut campur perempuan didalamnya.

Akan tetapi dalam faktanya, dalam aspek-aspek tertentu, perempuan dipandang sebagai sosok yang kurang diperlukan keberadaannya. Dalam kebudayaan Jawa pernah menempatkan perempuan sebagai the second sex yang tercermin dalam ungkapan-ungkapan proverbial yang sangat mengunggulkan lelaki. Ungkapan swarga nunut neraka katut, yang berarti bahwa kebahagiaan atau penderitaan isteri hanya tergantung pada suami, adalah contoh dimana perempuan dianggap tidak berperan dalam kehidupan (Imam Ahmad (Eds.), 1993: 50). Ditambah lagi, anggapan bahwa perempuan itu irrasional atau emosional sehingga perempuan tidak bisa tampil sebagai pemimpin, berakibat munculnya sikap yang menempatkan perempuan pada posisi yang tidak penting dalam kehidupan (Mansour Fakih, 2007: 15). Anggapan bahwa perempuan itu mempunyai sifat rajin dalam mengelola, menjaga dan memelihara kerapian, serta tidak cocok untuk menjadi kepala keluarga telah mengakibatkan tumbuhnya tradisi dan keyakinan masyarakat bahwa kaum perempuan yang harus bertanggung jawab atas terlaksananya semua pekerjaan domestik rumah tangga.

Seiring dengan berjalannya waktu, semua anggapan yang menyatakan bahwa kaum perempuan itu dianggap rendahan, keberadaannya kurang diperlukan, lemah atau yang lainnya itu terbantahkan. Perempuan memiliki hak yang sama dengan lakilaki dan kewajiban yang sama pula dengan kaum laki-laki (Amelia Fauzia (Eds.), 2004: 29). Budaya baru di Indonesia juga telah memperlihatkan perubahannya, dimana banyak kaum perempuan yang mampu berdiri sejajar dengan kaum laki-laki dan mampu melakukan banyak pekerjaan yang dulu dianggap tidak bisa dilakukan oleh perempuan.

Seorang perempuan juga mempunyai tugas-tugas yang tidak kalah pentingnya dengan tugas seorang 
laki-laki sebagai bapak. Alangkah baiknya bila pada masa sekarang ini kaum perempuan mempunyai pengetahuan dan pandangan hidup yang lebih luas. Terlebih lagi di masa sekarang sudah tidak adanya lagi pengekangan atau pembatasan terhadap kaum perempuan dalam memperoleh pendidikan. Baik laki-laki maupun perempuan mempunyai hak dan kedudukan yang sama dalam menempuh atau memperoleh pendidikan.

Seorang wanita hendaknya mempunyai atau bersifat multifungsional. Wanita yang multifungsional ialah wanita yang tidak hanya berfungsi sebagai istri yang bertugas melayani anak-anak dan suaminya, kemudian mengurusi segala keperluan mereka. Tetapi, seorang perempuan harus mampu menggunakan tenaga atau energinya untuk beraktivitas dan berkarya sekreatif mungkin, sehingga mampu berlomba dengan masyarakat di luar rumah tangganya. Perempuan Indonesia harus mempunyai kesadaran diri dan tingkat emansipasi yang tinggi sehingga dapat menjadi salah satu unsur perjuangan bangsa Indonesia yang sama kemampuan dan haknya dengan unsur lain.

Sekarang ini emansipasi perempuan sudah diakui adanya oleh seluruh elemen yang ada, sehingga dapat memberikan kemudahan dan kelancaran untuk terus berkarya tanpa adanya ancaman yang mencekam diri mereka. Seiring dengan perkembangan zaman, perempuan masa kini harus tampil menjadi figur yang penting di tengah-tengah kehidupan masyarakat. Harus berpartisipasi dalam usaha memajukan berbagai bidang kehidupan yang mana tidak kalah kualitasnya dengan hasil kerja kaum laki-laki. Contohnya dalam kemajuan budaya, pendidikan, ekonomi, sosial maupun teknologi.
Keterlibatan perempuan dalam sebuah budaya atau tradisi juga cukup besar. Dalam budaya dan tradisi tertentu, perempuan mendapatkan tempat atau peranan yang terhormat di masyarakat Indonesia. Bahkan di daerah Sumatera Barat, terdapat adat matrilineal yang sangat kuat dimana peran perempuan begitu kuat di dalam masyarakat adat dan keluarganya (Dadi Darmadi (Eds.), 2004: 144). Seperti halnya dengan contoh tersebut di atas, dalam tradisi upacara bersih desa, peran kaum perempuan sangat penting, sehingga keberadaan mereka tidak dapat dipandang sebelah mata.

Untuk itu, maka penelitian tentang peran perempuan dalam tradisi upacara bersih desa di Desa Kiringan Kecamatan Takeran Kabupaten Magetan menarik untuk diteliti.

\section{Tujuan}

Dalam mengadakan penelitian tidak terlepas dari tujuan yang hendak dicapai, sebab tujuan penelitian tersebut akan memberi arah dalam penelitian. Adapun yang menjadi tujuan dari penelitian ini adalah untuk mengetahui proses tradisi upacara bersih desa di Desa Kiringan Kecamatan Takeran Kabupaten Magetan. Selain itu, untuk mengetahui peran perempuan dalam tradisi upacara bersih desa di Desa Kiringan Kecamatan Takeran Kabupaten Magetan.

\section{Metode}

Jenis penelitian deskriptif kualitatif (Sutopo, 2006). Data diperoleh dari sumber primer dan sekunder berupa keterangan atau fakta dari informan dan peristiwa atau aktivitas serta dokumen dan arsip lain yang relevan. Pengumpulan data primer dilakukan dengan teknik wawancara dan observasi langsung. Sampel informan dipilih secara selektif. 
Kegiatan validasi data melalui triangulasi sumber. Data yang sama atau sejenis, akan lebih valid kebenarannya bila digali dari beberapa sumber data yang berbeda dengan membandingkan data sejenis yang diperoleh dari sumber lain yang berbeda, baik kelompok sumber sejenis maupun sumber yang berbeda jenisnya (Emzir, 2011: 82). Analisis data dengan analisis interaktif (Milles dan Huberman, 1992: 15-20).

\section{Hasil Penelitian}

A. Prosesi Tradisi Upacara Bersih Desa Di Desa Kiringan Kecamatan Takeran Kabupaten Magetan

1. Pengertian dan Fungsi Upacara Bersih Desa Di Desa Kiringan Kecamatan Takeran Kabupaten Magetan

Upacara bersih desa merupakan sebuah tradisi tahunan yang rutin digelar setiap setahun sekali. Tradisi ini dilaksanakan pada bulan Muharram atau yang oleh masyarakat Jawa biasa disebut dengan bulan Suro. Ketika akan melaksanakan tradisi bersih desa biasanya dicari hari baiknya terlebih dahulu agar dalam prosesinya nantinya dapat berjalan lancar, biasanya mengambil hari Kamis Kliwon atau Jum'at Kliwon (wawancara dengan beberapa informan, diantaranya Sumiran/modin dan Heri, 29 April 2013).

Sebuah tradisi yang merupakan salah satu wujud syukur masyarakat terhadap Tuhan Yang Maha Esa dari hasil panen, serta untuk membersihkan desa dari segala balak atau bencana. Tradisi bersih desa ini berfungsi untuk mempererat rasa kegotong royongan serta kekeluargaan masyarakat, sekaligus juga berfungsi untuk melestarikan tradisi masyarakat setempat (wawancara dengan beberapa informan, diantaranya Marmi dan Parti, 23 April 2013). Menurut beberapa informan, bersih desa bertujuan untuk mengirim do'a kepada babad desa/dusun (wawancara dengan beberapa informan, diantaranya Sumiran/modin dan Purwanto, 29 April 2013).

Masyarakat percaya bahwa apabila tradisi tersebut tidak dilaksanakan, desa mereka akan mendapatkan balak atau bencana. Karena alasan itulah hingga saat ini masyarakat Desa Kiringan, khususnya warga di Dusun Ganggong masih melestarikan tradisi tersebut secara turun temurun (wawancara dengan beberapa informan, diantaranya Lasmi, Marmi, dan Puah, 24 April 2013).

2. Rangkaian Acara Upacara Bersih Desa Di Desa Kiringan Kecamatan Takeran Kabupaten Magetan

Rangkaian dari tradisi upacara bersih desa di Desa Kiringan berupa:

a. Membersihkan Makam

Kegiatan mbersihkan makam dilakukan oleh seluruh warga setempat. Kegiatan bersihbersih lingkungan ini dilakukan oleh seluruh warga yang dipimpin oleh kepala dusun dan tokoh masyarakat. Kegiatan pembersihan makam ini dilakukan secara bersama-sama dengan gotong-royong. Kegiatan bersih-bersih makam ini dilakukan oleh kaum laki-laki. Semua areal pemakaman dibersihkan, terutama makam babad dusun atau cikal bakal dusun Ganggong yang bernama Mas Joko Purnomo. Selain membersihkan makam, ada juga warga yang membersihkan lingkungan tempat tinggalnya. Kegiatan membersihkan makam ini dilakukan di pagi hari sebelum 
acara selamatan, terkadang juga dilakukan sehari sebelum acara bersih desa (wawancara dengan beberapa informan, diantaranya Purwanto dan Suyadi, 29 April 2013).

b. Selamatan Acara selamatan dilakukan di Punden (makam babad desa). Setiap rumah dianjurkan untuk membawa nasi berkat beserta kelengkapannya ke Punden. Meskipun setiap rumah tidak diwajibkan untuk membawa nasi berkat, tetapi hampir setiap rumah atau kepala keluarga membawa. Hal ini disebabkan karena kesadaran dan rasa solidaritas yang cukup tinggi dari setiap warganya.

Nasi tersebut nantinya juga akan dibagikan kepada warga dan dimakan bersama-sama. Apabila nanti masih ada sisa makanan, makanan tersebut juga dibagikan lagi kepada warga untuk dibawa pulang. Acara selamatan dilakukan di makam bertujuan untuk mengingatkan manusia bahwa nantinya juga akan mati. Karena itu harus senantiasa rajin beribadah dan membersihkan diri dari hal-hal yang negatif (wawancara dengan beberapa informan, diantaranya Parti, Komsiyah dan Marinah, 25 April 2013).

c. Penutup

Acara penutup berupa pemanjatan do'a permohonan keselamatan desa, dan diakhir acara ditutup dengan acara langen beksan. Acara langen beksan dilakukan sebanyak dua kali. Pertama, dilakukan pada siang hari setelah acara selamatan di Punden. Yang kedua, dilakukan pada malam harinya di rumah perangkat desa (Kamituwo). Langen beksan didahului dengan tari Gambyong atau yang juga biasa disebut dengan Tayub yang dibuka oleh Kepala Desa beserta perangkatnya. Acara langen beksan ini merupakan acara hiburan bagi masyarakat setempat. Dalam acara ini biasanya selalu menghadirkan tledhek yang menari sekaligus nyindhen. Dalam acara ini biasanya terdapat tiga sampai lima tledhek yang hadir (wawancara dengan beberapa informan, diantaranya Marmi dan Sumiran, 25 April 2013).

C. Peran Perempuan Dalam Tradisi Upacara Bersih Desa Di Desa Kiringan Kecamatan Takeran Kabupaten Magetan

Dalam kehidupan sosial di masyarakat, peran atau keterlibatan kaum perempuan cukup besar. Begitu juga dalam aspek budaya, peran kaum perempuan cukup besar. Dalam tradisi-tradisi di masyarakat seperti upacara bersih desa, tidak hanya kaum laki-laki saja yang turut berpartisipasi, kaum perempuan juga ikut serta di dalamnya. Meskipun perempuan tidak berperan sebagai aktor utama, tetapi keberadaannya sangat penting. Tanpa keberadaan dari mereka tradisi tersebut tidak akan terlaksana. Dari hasil wawancara dengan beberapa informan diperoleh informasi mengenai peran dari kaum perempuan dalam persiapan maupun pelaksanaan tradisi tersebut. Peran dari kaum perempuan yaitu:

\section{Pembuat Uborampe}

$\begin{array}{lr}\text { Uborampe } & \text { adalah } \\ \text { yang } \\ \text { perlengkapan } & \text { dalam } \\ \text { diperlukan/digunakan } & \text { tradisi } \\ \text { acara selamatan dalam } & \text { tradisan } \\ \text { upacara bersih desa maupun } \\ \text { dalam tradisi lainnya. Penggunaan } \\ \text { uborampe tersebut merupakan } \\ \text { simbol atas pemikiran-pemikiran }\end{array}$


yang tidak terjangkau, sehingga dengan penggunaan uborampe tersebut mereka dapat mengekspresikan cara beribadah yang khusyuk. Berbagai macam sesaji atu uborampe yang terdapat dalam ritual kenduri merupakan salah satu bentuk aktualisasi diri yang dilakukan semata-mata untuk mendekatkan diri dengan Tuhan Yang Maha Esa. Kemampuan akal manusia yang terbatas mengenai pemahaman terhadap religi mendorong manusia untuk melakukan berbagi macam tindakan untuk memuaskan perasaan dan ras ingin tahu mereka, dan salah satu jalannya adalah dengan menggunakan berbagai macam uborampe atau sesaji dalam ritualritual tertentu.

Tradisi selamatan atau kenduri ini merupakan suatu tradisi atau upacara yang pada dasarnya adalah untuk memohon kepada Allah agar hajatnya dilancarakan atau dipermudah. Hajat tersebut misalnya, agar diberi keselamatan, dilancarkan segala urusan dan kepentingannya dan bisa juga untuk mendoakan orang yang sudah meninggal agar diterima di sisi-Nya, sehingga orang yang memiliki hajat tersebut bisa menyelenggarakan ritual kenduri untuk memperlancar hajatnya tersebut. Tradisi selamatan merupakan ajaran nenek moyang kita yaitu orang Jawa yang pada intinya adalah mengajari kita untuk bersedekah, sehingga selamatan atau kenduri adalah upacara bersedekah makanan (wawancara dengan beberapa informan, diantaranya Heri dan Suyadi, 29 April 2013).

dalam $\begin{gathered}\text { Uborampe atau sesaji } \\ \text { ritual }\end{gathered}$

merupakan sarana utama dalam ritual. Tanpa adanya keberadaan uborampe atau sesaji, maka tradisi selamatan tidak akan ada maknanya. Hal ini disebabkan karena ada maksud atau makna tersendiri dari isi uborampe tersebut. Dengan adanya uborampe atau sesaji tersebut masyarakat akan merasa ibadah kepada Tuhan menjadi lebih sempurna. Sesaji atau sajen yang digunakan dalam ritual selamatan atau kenduri tersebut memiliki makna tersendiri.

Uborampe ini ada banyak macamnya, seperti nasi kuning, ingkung, dan kembang, dan lain sebagainya. Dalam hal ini, para kaum perempuan yang bertugas untuk memenuhinya karena kaum perempuan dianggap sebagai seseorang yang lebih ahli atau mampu dalam hal masak memasak atau yang berkaitan dengan masalah dapur lainnya.

Acara atau kegiatan pertama dalam rangkaian upacara bersih desa adalah kegiatan membersihkan makam, khususnya membersihkan makam atau Punden babad dusun setempat (Dusun Ganggong) yang bernama Mas Joko Purnomo. Kegiatan membersihkan makam ini dilakukan oleh seluruh warga setempat yang berjenis kelamin laki-laki dari usia anak-anak sampai orang tua. Pada saat yang bersamaan, para kaum perempuan di rumahnya masingmasing mengemban tugas untuk membuat uborampe guna acara selamatan di Punden. Tidak terdapat aturan khusus mengenai apakah yang perempuan yang memasak itu masih perawan atau sudah berkeluarga. Hanya saja, setiap kepala keluarga dianjurkan untuk membawa seperangkat 
uborampe berupa nasi berkat untuk acara selamatan. Semisal di dalam rumah terdapat dua kepala keluarga yang sudah mampu secara materiil, maka dianjurkan juga untuk membawa dua pasang ceting nasi berkat. Khusus untuk isteri perangkat desa diwajibkan untuk membuat dan membawa uborampe berupa nasi berkat ke Punden.

Tata cara dalam proses memasak makanan untuk uborampe juga tidak ada aturan khususnya. Proses memasak dilakukan layaknya memasak makanan untuk sehari-hari di rumah. Hal pertama yang perlu dipersiapkan adalah bahan-bahan untuk memasak serta peralatan memasak yang diperlukan, misalnya panci, wajan, baskom, ceting, dan lain sebagainya. Apabila bahan dan peralatan sudah tersedia semua, maka proses memasak dapat dimulai. Sebuah pantangan yang juga dipercaya oleh masyarakat setempat adalah, ketika memasak makanan yang akan dibawa untuk acara selamatan di Punden tidak boleh dicicipi. Jika sampai dicicipi, makanan tersebut akan jatuh dalam perjalanan. Setelah makanan sudah masak dan sudah dimasukkan dalam wadahnya, yang bertugas membawa nasi berkat tersebut ke Punden adalah kaum laki-laki atau para suami yang sudah selesai mekakukan kerja bakti membersihkan makam (wawancara dengan beberapa informan, diantaranya Komsiyah dan Marinah, 24 April 2013).

Berikut ini adalah berbagai macam jenis dari isi uborampe yang biasanya terdapat dalam upacara bersih desa beserta makna yang terkandung di dalamnya:

\section{a. Tumpeng}

Tumpeng menurut orang Jawa merupakan ungkapan dari "metuo dalam kang lempeng", yang artinya manusia dalam menjalani hidup harus berada di jalan yang benar, jauh dari segala kesesatan dan kejahatan. Kehadiran tumpeng dalam tradisi selamatan pada budaya Jawa memberi makna yang mendalam, begitupun dalam komponen-komponen tumpeng itu sendiri. Nasi tumpeng yang
berbentuk ditempatkan di tengah-tengah dengan berbagai macam laukpauk disusun di sekelilingnya. Penempatan nasi dan lauk pauk seperti ini disimbolkan sebagai gunung dan tanah yang subur di sekelilingnya. Tanah di sekeliling gunung dipenuhi dengan berbagai macam sayuran dari tumbuhtumbuhan dan lauk-pauk sebagai simbol atau tanda yang berasal dari alam (hasil tanah). Pemilihan lauk-pauk dalam tumpeng juga didasari oleh kebijaksanaan yang didapat dari belajar terhadap alam. Tumpeng merupakan simbol ekosistem kehidupan. Kerucut nasi yang menjulang tinggi melambangkan keagungan Tuhan Yang Maha Pencipta alam beserta isinya, sedangkan aneka lauk-pauk dan sayuran merupakan simbol dari isi alam ini.

Selain dari bentuknya, makna tumpeng juga dapat dilihat dibalik warna dari nasi tumpeng tersebut. Ada dua warna dominan dari nasi tumpeng, yaitu warna putih dan kuning. Warna putih 
melambangkan kesucian, ada juga yang berpendapat nasi putih melambangkan keberuntungan dan penyajian nasi putih tersebut mengandung permohonan agar semua pihak yang terlibat dapam upacara dapat selamat dan dikaruniai banyak rezeki. Warna kuning seperti emas melambangkan limpahan rezeki, kekayaan, dan kemakmuran. Dengan diberinya sesaji ini diharapkan akan semakin bertambah banyak kekayaan yang dimiliki.

\section{b. Ingkung}

Ingkung merupakan uborampe yang berupa ayam kampung yang dimasak secara utuh dengan diberi bumbu opor, kelapa, dan daun salam. Ingkung mengandung makna untuk menyucikan seseorang yang punya hajat maupun tamu yang hadir pada acara selamatan. Uborampe ingkung ini lebih dimaknai sebagai simbol permohonan ampun bagi seluruh penduduk desa serta dijauhkan segala dosa dan kesalahan.

c. Pisang

Penggunaan buah
pisang dalam uborampe
dimaksudkan agar pelaku
ritual dapat menjalankan
hidup sebagaimana watak
pisang, yaitu ajur ajer atau
dapat hidup dimana saja dan
selalu menyesuaikan diri
dengan lingkungannya. Dan
diharapkan juga semua bagian
dari dirinya dapat memberi
manfaat layaknya pohon
pisang.

d. Kacang panjang

\begin{tabular}{lrr}
\multicolumn{2}{c}{ Dalam } & kehidupan \\
sehari-hari & semestinya \\
manusia & selalu & berfikir
\end{tabular}

panjang (nalar kang mulur) serta tidak boleh memiliki fikiran yang jelek (mulur mung krete nalar pating saluwir). Dengan begitu manusia akan selalu dapat menghadapi berbagi hal dan situasi kondisi dengan penuh kesadaran dan bijaksana.

e. Cabai Merah

Melambangkan sifat keberanian dan tekat kuat untuk menegakkan kebenaran.

\section{f. Kecambah}

\section{Kecambah}

merupakan simbol dari benih atau bakal manusia yang akan selalu tumbuh seperti kecambah.

\section{g. Jajanan Pasar}

Makna jajanan pasar yakni sebagai sedekah untuk keselamatan hidup, terutama selamat dalam bidang rohani, batin atau selamat dari gangguan makhluk ghaib. Jajanan pasar adalah lambang dari sesrawungan (hubungan kemanusiaan, silaturrahmi) dan lambang kemakmuran. Manusia dalam menjalani kehidupan di dunia ini harus senantiasa menjalin hubungan silaturrahmi atau kekeluargaan dengan sesama manusia.

h. Apem

Mempunyai makna berupa ampunan dari Tuhan Yang Maha Esa. Dengan adanya apem ini diharapkan manusia akan memperoleh ampunan dari Tuhan Yang Maha Esa.

\section{i. Kemenyan}

Kemenyan digunakan sebagai sarana permohonan pada waktu seseorang mengucapkan permohonan berupa do'a atau mantra. Kemenyan melambangkan makanan enak bagi roh halus. 
Dengan diberi kemenyan, diharapkan mereka (roh halus) tidak akan mengganggu manusia.

j. Kembang telon atau kembang boreh

Merupakan uborampe berupa berbagai jenis bunga, biasanya terdiri dari bunga kenanga, kantil, mawar, dan lain-lain. Uborampe ini melambangkan kejernihan hati dan kesesuaian dengan alam. Bahan-bahan yang digunakan dalam acara selamatan masyarakat Desa Kiringan saat ini tidak selengkap dulu. Hal ini disebabkan karena perkembangan zaman yang semakin modern. Selain itu, juga karena semakin pudarnya pengaruh budaya Hindu di dalam masyarakat akibat masuk dan berkembangnya agama Islam. Masyarakat setempat juga semakin menyadari bahwa ada hal-hal tertentu yang sekiranya tidak bisa diterima oleh akal manusia secara logis, maka harus segera ditinggalkan.

$$
\text { Seperti halnya }
$$

penggunaan uborampe yang berbagai macam jenisnya dengan disertai makna-makna tersendiri didalamnya. Misalnya uborampe berupa kemenyan yang mempunyai makna sebagai sarana permohonan pada waktu seseorang mengucapkan permohonan berupa do'a atau mantra. Kemenyan melambangkan makanan enak bagi roh halus. Dengan diberi kemenyan, diharapkan mereka (roh halus) tidak akan mengganggu manusia. Hal tersebut tidak dapat diterima oleh sebagian besar masyarakat karena kebiasaan menggunakan kemenyan justru menjurus pada tindakan musyrik atau menyekutukan Tuhan Yang Maha Esa. Masyarakat memang mempercayai bahwa di luar dunia manusia terdapat dunia lain yang dihuni oleh makhluk halus. Agar manusia tidak diganggu oleh makhluk halus tersebut yaitu dengan jalan rajin beribadah, bukan menggunakan kemenyan atau yang lainnya.

Dalam upacara bersih desa di Desa Kiringan, uborampe yang digunakan adalah berupa nasi berkat dan kembang. Pada umumnya, yang selalu ada dalam nasi berkat tersebut adalah nasi kuning atau putih, ingkung, dan pisang. Dahulu, nasi tersebut diletakkan dalam suatu wadah yang terbuat dari pelepah pisang yang biasa disebut dengan encek. Encek merupakan wadah atau nampan yang berbentuk bujursangkar dengan ukuran kurang lebih $40 \mathrm{~cm} \times 40 \mathrm{~cm}$, terbuat dari pelepah pisang sebagai bagian tepinya dan alasanya berupa bambu yang dianyam jarang secara saling menyilang. Karena adanya perubahan zaman yang semakin modern, sekarang kebiasaan tersebut tidak berlaku lagi. Sekarang, nasi diletakkan di wadah berupa ceting atau baskom. Setiap rumah dianjurkan untuk mengeluarkan atau membawa sepasang ceting yang berisi nasi beserta kelengkapannya untuk acara selamatan di Punden (wawancara dengan beberapa informan, diantarnya Marinah dan Lasmi, 25 April 2013).

Jenis makanan yang terdapat dalam dalam ceting tidak ditentukan, tergantung pada kemampuan setiap warga yang mengeluarkan. Makanan yang diberikan oleh warga biasanya 
berupa nasi putih, tahu, tempe, urap, pelas, telur, dan lainnya. Warga yang mampu biasanya juga menyertakan ingkung atau masakan ayam di dalamnya. Khusus untuk perangkat desa diwajibkan untuk memberikan nasi berkat yang berisi ingkung yang masih utuh dan pisang setangkep.

Selain menyediakan uborampe berupa makanan, perlu disediakan juga uborampe yang berupa kembang terdiri dari berbagai jenis kembang atau yang biasa dikenal dengan kembang telon atau kembang boreh. Jenis kembang yang biasanya digunakan yaitu kantil, kenanga, mawar, dan lain sebagainya. Kembang tersebut nantinya digunakan untuk nyekar makam tokoh babad dusun Ganggong yang bernama Mas Joko Purnomo. Yang bertugas untuk menyediakan adalah isteri perangkat desa saja.

\section{Sebagai Tledhek}

Peran lain dari perempuan dalam tradisi upacara bersih desa adalah sebagai tledhek atau masyarakat Desa Kiringan biasa menyebutnya dengan kledhek. Dalam acara penutup upacara bersih desa biasanya selalu menampilkan acara hiburan berupa langen beksan. Langen beksan ini berupa kesenian Tayub atau Gambyong. Peran tledhek dalam acara hiburan ini adalah sebagai penari dan penyanyi (nyindhen).

Keberadaan kesenian Tayub ini merupakan pelengkap dalam tradisi bersih desa, jika seandainya tidak adapun juga tidak dipermasalahkan karena keberadaan kesenian Tayub adalah sebagai hiburan semata. Begitu juga dengan keberadaan tledhek, tledhek hanya sebatas sebagai hiburan bagi warga. Tledhek merupakan pelengkap dalam kesenian Tayub. Tanpa adanya tledhek yang menawan dan lemah gemulai saat menari, maka kesenian Tayub tidak akan menarik dilihat. Tarian Tayub akan lebih hidup dan semarak apabila tledhek bisa tampil secara ramah, genit, trampil gerak tariannya dan menggemaskan (wawancara dengan beberapa informan, diantaranya Suyadi, Parti dan Lasmi, 29 April 2013).

Para pelaku atau pemain kesenian Tayub berasal dari luar daerah Kiringan. Biasanya mereka berasal dari daerah Nglembah (Dolopo), Ngawi, dan Magetan. Dalam kesenian Tayub biasanya menghadirkan tiga sampai lima orang tledhek, kadang juga lebih dari itu. Acara hiburan ini digelar dua kali, yaitu siang hari di Punden usai acara selamatan dan malam hari di rumah perangkat desa (kamituwo).

Pelaksanaan kesenian langen beksan atau Tayub di Desa Kiringan pada masa dahulu dengan masa kini sudah sangat berbeda baik dalam berbusana dari para tledhek atau bersikap. Dahulu, dalam acara hiburan tersebut selalu diwarnai dengan budaya nyawer dan mabukmabukan atau minum minuman keras. Kebiasaan negatif tersebut dahulu disebut dengan Tiga C, yaitu ciu (minuman keras), colek, dan cium sebagai unsur budaya asing yang telah mencemari kesenian Tayub yang sakral (wawancara dengan beberapa informan, diantaranya Sumiran dan Purwanto, 29 April 2013). 


\section{Pembahasan}

Salah satu tradisi yang hingga saat ini masih dilestarikan oleh masyarakat Jawa tradisional adalah tradisi upacara bersih desa. Salah satu tradisi tradisional Jawa yang tidak hanya mengandung nilai fungsi magis spiritual, tetapi juga mempunyai nilai fungsi sosial untuk mempererat hubungan sesama manusia. Semakin maju dan berkembangnya zaman ternyata tidak menyurutkan semangat warga di Dusun Ganggong Desa Kiringan Kecamatan Takeran Kabupaten Magetan untuk terus melestarikan salah satu tradisi kejawen tersebut. Tradisi upacara bersih desa di daerah ini digelar setiap tahun sekali pada bulan Suro atau Muharram. Orang Jawa menganggap bulan Suro sebagai bulan yang suci dan sakral. Kebanyakan dari mereka mengharapkan untuk ngalap berkah dari hari besar suci ini. Untuk waktu pelaksanaannya pun juga ada pemilihan harinya agar dalam persiapan maupun pelaksanaan acara tersebut dapat berjalan dengan lancar. Upacara bersih desa ini biasanya dilakukan pada hari Kamis Kliwon atau Jum'at Kliwon.

Sebuah tradisi yang merupakan salah satu wujud syukur masyarakat terhadap Tuhan Yang Maha Esa terhadap hasil panen, serta untuk membersihkan desa dari segala balak atau bencana. Tradisi bersih desa ini berfungsi untuk mempererat rasa kegotong royongan serta kekeluargaan masyarakat, sekaligus juga berfungsi untuk melestarikan tradisi masyarakat. Menurut Sumiran/modin desa setempat, bersih desa juga bertujuan untuk mengirim do'a kepada babad desa/dusun yang bernama Mas Joko Purnomo.

Peran serta perempuan dalam kehidupan sosial budaya di dalam masyarakat itu cukup besar. Terlebih lagi setelah munculnya berbagai gerakan tranformasi feminisme yang bertujuan untuk mengangkat derajat serta kedudukan perempuan agar dapat sejajar dan bersaing dengan kaum lakilaki di dunia luar. Begitu juga dalam aspek budaya, peran kaum perempuan cukup besar. Akan tetapi dalam aspekaspek tertentu, perempuan dipandang sebagai sosok yang kurang diperlukan keberadaannya. Dalam kebudayaan Jawa pernah menempatkan perempuan sebagai the second sex yang tercermin dalam ungkapan-ungkapan proverbial yang sangat mengunggulkan lelaki. Ungkapan swarga nunut neraka katut, yang berarti bahwa kebahagiaan atau penderitaan isteri hanya tergantung pada suami, adalah contoh dimana perempuan dianggap tidak berperan dalam kehidupan (Imam Ahmad (Eds.), 1993: 50). Hal senada juga disampaikan oleh Ganis Setyaningrum (2001: 22) bahwa di sebagian besar masyarakat masih kuat tradisi yang mendiskreditkan perempuan dengan menempatkan kaum hawa sebagai makhluk yang lemah gemulai, sebagai second person atau hanya sebagai konco wingking saja.

Selain itu, karakter perempuan yang irrasional atau emosional menyebabkan perempuan tidak bisa tampil sebagai pemimpin, berakibat munculnya sikap yang menempatkan perempuan pada posisi yang tidak penting (Mansour Fakih, 2007: 15). Perempuan yang mempunyai sifat rajin dalam mengelola, menjaga dan memelihara kerapian, serta tidak cocok untuk menjadi kepala keluarga telah mengakibatkan tumbuhnya tradisi dan keyakinan masyarakat bahwa kaum perempuan yang harus bertanggung jawab atas terlaksananya semua pekerjaan domestik rumah tangga.

Teori yang telah dipaparkan oleh Imam Ahmad, Ganis maupun Mansour Fakih mengenai peran perempuan di atas telah terjadi kesinambungan dengan fakta yang ada 
di lapangan, bahwa perempuan sebenarnya memiliki peranan penting meskipun bukan sebagai peran utama. Dalam banyak hal sering terjadi bias gender di setiap kegiatan yang melibatkan perempuan. Padahal perempuan juga banyak terlibat dan berperan penting dalam banyak bidang kehidupan. Banyak juga kaum perempuan yang turut serta dalam usaha pembangunan nasional. Akan tetapi, keterlibatan atau peran serta perempuan dalam kegiatan-kegiatan tersebut sering kali tak nampak. Yang terlihat sebagai pelaku atau berperan utama adalah laki-laki. Perempuan sering kali ditempatkan pada posisi kedua setelah laki-laki. Kurangnya kesempatan bagi perempuan untuk menjadi seorang pemimpin menyebabkan perempuan hanya diberi tugas untuk mengerjakan tugas-tugas sekunder.

Dalam tradisi upacara bersih desa di Desa Kiringan, pelaku utama dalam persiapan maupun pelaksanaannya adalah laki-laki, sedangkan perempuan hanya sebagai pelaku kedua. Sebagai buktinya, yang berperan sebagai pemimpin dalam pelaksanaan upacara bersih desa tersebut adalah laki-laki. Perempuan hanya diberi tugas untuk mengerjakan peran sekunder yang berkaitan dengan tugas domestik seorang perempuan yaitu sebagai pembuat uborampe dan sebagai tledhek.

Dengan demikian jelas terbukti bahwa dalam segala bentuk kegiatan acara maupun pembangunan, khususnya pelaksanaan bersih desa di Desa Kiringan peran perempuan hanya dipandang sebagian kecil saja, meskipun besar sumbangsih perempuan dalam persiapan maupun pelaksanaan bersih desa tersebut, laki-lakilah yang tetap menjadi pelaku utama.

Dalam penelitian ini, peran perempuan dalam tradisi upacara bersih desa di Desa Kiringan Kecamatan
Takeran Kabupaten Magetan dipisahkan dalam dua pembagian waktu, yaitu peran perempuan pada saat persiapan atau sebelum pelaksanaan upacara bersih desa dan peran perempuan pada waktu pelaksanaan upacara bersih desa.

\section{A. Peran Perempuan Pada Waktu Persiapan atau Sebelum Pelaksanaan Tradisi Upacara Bersih Desa Di Desa Kiringan Kecamatan Takeran Kabupaten Magetan}

Dari hasil penelitian dengan metode wawancara dengan beberapa informan, diperoleh data mengenai peran dari kaum perempuan pada waktu persiapan atau sebelum pelaksanaan tradisi upacara bersih desa di Desa Kiringan, yaitu sebagai:

\section{Pembuat Uborampe}

Uborampe atau sesaji adalah perlengkapan yang diperlukan/digunakan dalam acara selamatan dalam tradisi upacara bersih desa maupun dalam tradisi lainnya. Muhammad Solikin (dalam Timbang Prasojo, 2012: 3) menyatakan bahwa simbol-simbol ritual merupakan ekspresi atau pengejawantahan dari penghayatan dan pemahaman akan realitas yang tak terjangkau, sehingga menjadi "Yang Sangat Dekat". Dengan simbolsimbol berupa uborampe tersebut terasa bahwa Alloh selalu hadir dan selalu terlibat menyatu dengan dirinya. Purwadi (dalam Timbang Prasojo, 2012: 4) mengungkapakan bahwa sajian ialah suatu rangkaian makanan kecil, benda-benda kecil, bunga-bungaan serta barang hiasan yang semuanya disusun menurut konsepsi keagamaan, sehingga merupakan lambang (simbol) yang mengandung arti.

Penggunaan uborampe

tersebut merupakan simbol atas pemikiran-pemikiran yang tidak terjangkau, sehingga dengan penggunaan uborampe tersebut 
mereka dapat mengekspresikan cara beribadah yang khusyuk. Berbagai macam sesaji atu uborampe yang terdapat dalam ritual kenduri merupakan salah satu bentuk aktualisasi diri yang dilakukan semata-mata untuk mendekatkan diri dengan Tuhan Yang Maha Esa. Kemampuan akal manusia yang terbatas mengenai pemahaman terhadap religi mendorong manusia untuk melakukan berbagi macam tindakan untuk memuaskan perasaan dan ras ingin tahu mereka, dan salah satu jalannya adalah dengan menggunakan berbagai macam uborampe atau sesaji dalam ritual-ritual tertentu.

Tradisi selamatan atau kenduri ini merupakan suatu tradisi atau upacara yang pada dasarnya adalah untuk memohon kepada Allah agar hajatnya dilancarakan atau dipermudah. Hajat tersebut misalnya, agar diberi keselamatan, dilancarkan segala urusan dan kepentingannya dan bisa juga untuk mendoakan orang yang sudah meninggal agar diterima di sisi-Nya, sehingga orang yang memiliki hajat tersebut bisa menyelenggarakan ritual kenduri untuk memperlancar hajatnya tersebut. Tradisi selamatan merupakan ajaran nenek moyang kita yaitu orang Jawa yang pada intinya adalah mengajari kita untuk bersedekah, sehingga selamatan atau kenduri adalah upacara bersedekah makanan.

Uborampe atau sesaji dalam ritual selamatan merupakan sarana utama dalam ritual. Tanpa adanya keberadaan uborampe atau sesaji, maka tradisi selamatan tidak akan ada maknanya. Hal ini disebabkan karena ada maksud atau makna tersendiri dari isi uborampe tersebut. Dengan adanya uborampe atau sesaji tersebut masyarakat akan merasa ibadah kepada Tuhan menjadi lebih sempurna. Sesaji atau sajen yang digunakan dalam ritual selamatan atau kenduri tersebut memiliki makna tersendiri.

Uborampe ini ada banyak macamnya, seperti nasi kuning, ingkung, dan kembang, dan lain sebagainya. Dalam hal ini, para kaum perempuan yang bertugas untuk memenuhinya karena kaum perempuan dianggap sebagai seseorang yang lebih ahli atau mampu dalam hal masak memasak atau yang berkaitan dengan masalah dapur lainnya.

Acara atau kegiatan pertama dalam rangkaian upacara bersih desa adalah kegiatan membersihkan makam, khususnya membersihkan makam atau Punden babad dusun setempat (Dusun Ganggong) yang bernama Mas Joko Purnomo. Kegiatan membersihkan makam ini dilakukan oleh seluruh warga setempat yang berjenis kelamin laki-laki dari usia anak-anak sampai orang tua. Pada saat yang bersamaan, para kaum perempuan di rumahnya masing-masing mengemban tugas untuk membuat uborampe guna acara selamatan di Punden. Tidak terdapat aturan khusus mengenai apakah yang perempuan yang memasak itu masih perawan atau sudah berkeluarga. Hanya saja, setiap kepala keluarga dianjurkan untuk membawa seperangkat uborampe berupa nasi berkat untuk acara selamatan. Semisal di dalam rumah terdapat dua kepala keluarga yang sudah mampu secara materiil, maka dianjurkan juga untuk membawa dua pasang ceting nasi berkat. Khusus untuk isteri perangkat desa diwajibkan untuk membuat dan membawa uborampe berupa nasi berkat ke Punden.

Tata cara dalam proses memasak makanan untuk uborampe 
juga tidak ada aturan khususnya. Proses memasak dilakukan layaknya memasak makanan untuk sehari-hari di rumah. Hal pertama yang perlu dipersiapkan adalah bahan-bahan untuk memasak serta peralatan memasak yang diperlukan, misalnya panci, wajan, baskom, ceting, dan lain sebagainya. Apabila bahan dan peralatan sudah tersedia semua, maka proses memasak dapat dimulai. Sebuah pantangan yang juga dipercaya oleh masyarakat setempat adalah, ketika memasak makanan yang akan dibawa untuk acara selamatan di Punden tidak boleh dicicipi. Jika sampai dicicipi, makanan tersebut akan jatuh dalam perjalanan. Setelah makanan sudah masak dan sudah dimasukkan dalam wadahnya, yang bertugas membawa nasi berkat tersebut ke Punden adalah kaum laki-laki atau para suami yang sudah selesai mekakukan kerja bakti membersihkan makam.

Berikut ini adalah berbagai macam jenis dari isi uborampe yang biasanya terdapat dalam upacara bersih desa beserta makna yang terkandung di dalamnya:

\section{k. Tumpeng}

Tumpeng menurut orang Jawa merupakan ungkapan dari "metuo dalam kang lempeng", yang artinya manusia dalam menjalani hidup harus berada di jalan yang benar, jauh dari segala kesesatan dan kejahatan. Kehadiran tumpeng dalam tradisi selamatan pada budaya Jawa memberi makna yang mendalam, begitupun dalam komponen-komponen tumpeng itu sendiri.

Nasi tumpeng yang berbentuk kerucut ditempatkan di tengah-tengah dengan berbagai macam lauk-pauk disusun di sekelilingnya. Penempatan nasi dan lauk pauk seperti ini disimbolkan sebagai gunung dan tanah yang subur di sekelilingnya. Tanah di sekeliling gunung dipenuhi dengan berbagai macam sayuran dari tumbuh-tumbuhan dan lauk-pauk sebagai simbol atau tanda yang berasal dari alam (hasil tanah).

Pemilihan lauk-pauk dalam tumpeng juga didasari oleh kebijaksanaan yang didapat dari belajar terhadap alam. Tumpeng merupakan simbol ekosistem kehidupan. Kerucut nasi yang menjulang tinggi melambangkan keagungan Tuhan Yang Maha Pencipta alam beserta isinya, sedangkan aneka lauk-pauk dan sayuran merupakan simbol dari isi alam ini.

Selain dari bentuk, makna tumpeng juga dapat dilihat dari balik warna nasi tumpeng tersebut. Ada dua warna dominan dari nasi tumpeng, yaitu warna putih dan kuning. Warna putih melambangkan kesucian, ada juga yang berpendapat nasi putih melambangkan keberuntungan dan penyajian nasi putih tersebut mengandung permohonan agar semua pihak yang terlibat dapam upacara dapat selamat dan dikaruniai banyak rezeki. Warna kuning seperti emas melambangkan limpahan rezeki, kekayaan, dan kemakmuran. Dengan diberinya sesaji ini diharapkan akan semakin bertambah banyak kekayaan yang dimiliki.

\section{l. Ingkung}

Ingkung merupakan uborampe yang berupa ayam kampung yang dimasak secara utuh dengan diberi bumbu opor, kelapa, dan daun salam. Ingkung mengandung makna untuk menyucikan seseorang yang punya hajat maupun tamu yang 
hadir pada acara selamatan. Uborampe ingkung ini lebih dimaknai sebagai simbol permohonan ampun bagi seluruh penduduk desa serta dijauhkan segala dosa dan kesalahan.

\section{m. Pisang}

Penggunaan buah pisang dalam uborampe dimaksudkan agar pelaku ritual dapat menjalankan hidup sebagaimana watak pisang, yaitu ajur ajer atau dapat hidup dimana saja dan selalu menyesuaikan diri dengan lingkungannya. Dan diharapkan juga semua bagian dari dirinya dapat memberi manfaat layaknya pohon pisang.

\section{n. Kacang panjang}

Dalam kehidupan seharihari semestinya manusia selalu berfikir panjang (nalar kang mulur) serta tidak boleh memiliki fikiran yang jelek (mulur mung krete nalar pating saluwir). Dengan begitu manusia akan selalu dapat menghadapi berbagi hal dan situasi kondisi dengan penuh kesadaran dan bijaksana.

\section{o. Cabai Merah}

Melambangkan sifat keberanian dan tekat kuat untuk menegakkan kebenaran.

\section{p. Kecambah}

Kecambah merupakan simbol dari benih atau bakal manusia yang akan selalu tumbuh seperti kecambah.

\section{q. Jajanan Pasar}

Makna jajanan pasar
yakni sebagai sedekah untuk
keselamatan hidup, terutama
selamat dalam bidang rohani,
batin atau selamat dari gangguan
makhluk ghaib. Jajanan pasar
adalah lambang dari sesrawungan
(hubungan kemanusiaan,
silaturrahmi) dan lambang
kemakmuran.

\section{r. Apem}

Mempunyai makna berupa ampunan dari Tuhan Yang Maha Esa. Dengan adanya apem ini diharapkan manusia akan memperoleh ampunan dari Tuhan Yang Maha Esa.

\section{s. Kemenyan}

Kemenyan digunakan sebagai sarana permohonan pada waktu seseorang mengucapkan permohonan berupa do'a atau mantra. Kemenyan melambangkan makanan enak bagi roh halus. Dengan diberi kemenyan, diharapkan mereka (roh halus) tidak akan mengganggu manusia.

t. Kembang telon atau kembang boreh

Merupakan uborampe berupa berbagai jenis bunga, biasanya terdiri dari bunga kenanga, kantil, mawar, dan lainlain. Uborampe ini melambangkan kejernihan hati dan kesesuaian dengan alam (wawancara dengan beberapa informan, diantaranya Marmi dan Sumiran, 23 April 2013).

Uraian mengenai berbagai macam uborampe di atas biasa digunakan pada pelaksanaan tradisi bersih desa di zaman dahulu. Bahanbahan yang digunakan dalam acara selamatan masyarakat Desa Kiringan saat ini tidak selengkap dulu. Hal ini disebabkan karena perkembangan zaman yang semakin modern. Selain itu, juga karena semakin pudarnya pengaruh budaya Hindu di dalam masyarakat akibat masuk dan berkembangnya agama Islam. Masyarakat setempat juga semakin menyadari bahwa ada hal-hal tertentu yang sekiranya tidak bisa diterima oleh akal manusia secara logis, maka harus segera ditinggalkan. 
Seperti halnya penggunaan uborampe yang berbagai macam jenisnya dengan disertai maknamakna tersendiri didalamnya. Misalnya uborampe berupa kemenyan yang mempunyai makna sebagai sarana permohonan pada waktu seseorang mengucapkan permohonan berupa do'a atau mantra. Kemenyan melambangkan makanan enak bagi roh halus. Dengan diberi kemenyan, diharapkan mereka (roh halus) tidak akan mengganggu manusia. Hal tersebut tidak dapat diterima oleh sebagian besar masyarakat karena kebiasaan menggunakan kemenyan justru menjurus pada tindakan musyrik atau menyekutukan Tuhan Yang Maha Esa. Masyarakat memang mempercayai bahwa di luar dunia manusia terdapat dunia lain yang dihuni oleh makhluk halus. Agar manusia tidak diganggu oleh makhluk halus tersebut yaitu dengan jalan rajin beribadah, bukan menggunakan kemenyan atau yang lainnya.

Dalam upacara bersih desa di Desa Kiringan, uborampe yang digunakan adalah berupa nasi berkat dan kembang. Pada umumnya, yang selalu ada dalam nasi berkat tersebut adalah nasi kuning atau putih, ingkung, dan pisang. Dahulu, nasi tersebut diletakkan dalam suatu wadah yang terbuat dari pelepah pisang yang biasa disebut dengan encek. Encek merupakan wadah atau nampan yang berbentuk bujursangkar dengan ukuran kurang lebih $40 \mathrm{~cm} \times 40 \mathrm{~cm}$, terbuat dari pelepah pisang sebagai bagian tepinya dan alasanya berupa bambu yang dianyam jarang secara saling menyilang. Karena adanya perubahan zaman yang semakin modern, sekarang kebiasaan tersebut tidak berlaku lagi. Sekarang, nasi diletakkan di wadah berupa ceting atau baskom. Setiap rumah dianjurkan untuk mengeluarkan atau membawa sepasang ceting yang berisi nasi beserta kelengkapannya untuk acara selamatan di Punden. Jenis makanan yang terdapat dalam dalam ceting tidak ditentukan, tergantung pada kemampuan setiap warga yang mengeluarkan. Makanan yang diberikan oleh warga biasanya berupa nasi putih, tahu, tempe, urap, pelas, telur, dan lainnya. Warga yang mampu biasanya juga menyertakan ingkung atau masakan ayam di dalamnya. Khusus untuk perangkat desa diwajibkan untuk memberikan nasi berkat yang berisi ingkung yang masih utuh dan pisang setangkep.

Selain menyediakan uborampe berupa makanan, perlu disediakan juga uborampe yang berupa kembang terdiri dari berbagai jenis kembang atau yang biasa dikenal dengan kembang telon atau kembang boreh. Jenis kembang yang biasanya digunakan yaitu kantil, kenanga, mawar, dan lain sebagainya. Kembang tersebut nantinya digunakan untuk nyekar makam tokoh babad dusun Ganggong yang bernama Mas Joko Purnomo. Yang bertugas untuk menyediakan adalah isteri perangkat desa saja.

B. Peran Perempuan Pada Waktu Pelaksanaan Tradisi Upacara Bersih Desa Di Desa Kiringan Kecamatan Takeran Kabupaten Magetan

Dari hasil penelitian dengan metode wawancara dengan beberapa informan, diperoleh data mengenai peran dari kaum perempuan pada waktu pelaksanaan tradisi upacara bersih desa di Desa Kiringan, yaitu:

Sebagai Tledhek

Peran lain dari perempuan dalam tradisi upacara bersih desa adalah sebagai tledhek atau 
masyarakat Desa Kiringan biasa menyebutnya dengan kledhek. Tledhek dalam bahasa Jawa ditulis dengan "taledhek" atau "tledek", diartikan sebagai seorang perempuan yang pekerjaannya menari juga nyindhen (menyanyi dengan iringan gamelan Jawa). Di dalam masyarakat ada yang menyebut tledhek dengan istilah kledhek, sinden, bahkan ada juga yang menyebut dengan istilah ronggeng (Jawa Barat) (Endang Caturwati, 2011). Primanto Nugroho (dalam Rachmad K. (Eds.), 2003: 11) berpendapat sebagai berikut:

Tledhek adalah jantung dari pesta (tari Jawa yang disebut tayuban atau tandakan) itu. Ia menari sendiri sejenak, dan kemudian menghampiri seorang dari tamu-tamu untuk menyampaikan selembar selendang tari kepadanya, sebuah undangan untuk menari bersamanya, atau sedikit di hadapan dan seputarnya. Dengan menghampiri gadis penari pada jarak dekat dan mencoba menyentuhnya, sementara ia menghindar adalah bagian dari kegembiraan. Sering kali penari laki-laki mengayunkan gelas minuman keras yang dari gelas itu ia minum ketika tarian berhenti.

Ketika kita mengkaji mengenai tledhek, maka secara tidak langsung kita akan mengkaji mengenai kesenian Tayub, karena antara tledhek dan Tayub itu berkaitan erat bahkan antara keduanya tak dapat dipisahkan karena keberadaannya saling melengkapi, bahkan ada juga yang menyamakan arti antara tledek dengan Tayub.

Menurut Rachmad K. Dwi Susilo (Eds.) (2003: 7) disebutkan bahwa Tayub dimaknai dengan kasukan jejogedan nganggo dijogedi ing tledhek. Dari pernyataan ini diperoleh pengertian tentang tledek, yaitu penari yang menari pada acara Tayuban. Karena alasan inilah mengapa banyak yang berpendapat bahwa tledhek dipadankan artinya dengan dengan Tayub dan Gambyong, yaitu sebuah pertunjukan hiburan yang selalu menghadirkan penari wanita dan mengajak penikmat (laki-laki) untuk menari bersama. Selain karena terkandung fungsi magis di dalamnya, kesenian Tayub dikembangkan sebagai sebuah tontonan atau acara-acara hiburan. Acara ini diselenggarakan sebagai ungkapan rasa bahagia dan bersyukur.

Menurut Endang Caturwati (2011: 172), ronggeng, sinden, tledhek dalam upacara ritual seni pertunjukan hingga kini masih diselenggarakan di beberapa daerah di Indonesia. Ada banyak kisah tentang kesenian Tayub, kesenian rakyat ini masih menjadi legenda dan seni yang terus digandrungi oleh warga masyarakat Jawa. Salah satunya menyatakan bahwa pada awal kelahirannya, Tayub merupakan ritual untuk persembahan demi kesuburan pertanian dalam bentuk upacara bersih desa. Melalui upacara bersih desa tersebut, perangkat desa mengajak warganya untuk melakukan tarian di sawah-sawah dengan harapan tanamannya menjadi subur dan terhindar dari hama dan mara bahaya.

Dalam acara penutup upacara bersih desa biasanya selalu menampilkan acara hiburan berupa langen beksan. Langen beksan ini berupa kesenian Tayub atau Gambyong. Peran tledhek dalam acara hiburan ini adalah sebagai penari dan penyanyi (nyindhen). 
Keberadaan kesenian Tayub ini merupakan pelengkap dalam tradisi bersih desa, jika seandainya tidak adapun juga tidak dipermasalahkan karena keberadaan kesenian Tayub adalah sebagai hiburan semata. Begitu juga dengan keberadaan tledhek, tledhek hanya sebatas sebagai hiburan bagi warga. Tledhek merupakan pelengkap dalam kesenian Tayub. Tanpa adanya tledhek yang menawan dan lemah gemulai saat menari, maka kesenian Tayub tidak akan menarik dilihat. Tarian Tayub akan lebih hidup dan semarak apabila tledhek bisa tampil secara ramah, genit, trampil gerak tariannya dan menggemaskan. Dalam fungsinya sebagai hiburan atau tontonan, hal utama yang ditonjolkan dalam kesenian Tayub adalah kenikmatan berperan serta penari laki-laki sebagai pengibing.

Para pelaku atau pemain kesenian Tayub berasal dari luar daerah Kiringan. Biasanya mereka berasal dari daerah Nglembah (Dolopo), Ngawi, dan Magetan. Dalam kesenian Tayub biasanya menghadirkan dua sampai tiga orang tledhek, kadang juga lebih dari itu. Acara hiburan ini digelar dua kali, yaitu siang hari di Punden usai acara selamatan dan malam hari di rumah perangkat desa (kamituwo). Pelaksanaan kesenian langen beksan atau Tayub di Desa Kiringan pada masa dahulu dengan masa kini sudah sangat berbeda baik dalam berbusana dari para tledhek atau bersikap. Dahulu, dalam acara hiburan tersebut selalu diwarnai dengan budaya nyawer dan mabukmabukan atau minum minuman keras. Kebiasaan negatif tersebut dahulu disebut dengan Tiga $\mathrm{C}$, yaitu ciu (minuman keras), colek, dan cium sebagai unsur budaya asing yang telah mencemari kesenian Tayub yang sakral.
Fenomena semacam inilah yang terkadang mendatangkan interpretasi bahwa Tayub adalah hiburan khusus bagi laki-laki karena tledhek sekadar sebagai objek pemuas hasrat keisengan lelaki. Interpretasi ini didukung oleh fakta, bahwa para perempuan desa yang ikut menonton pertunjukan tayub biasanya tidak terlibat aktif dalam arena tari. Begitu pula, apabila suami mereka mengibing dengan tledhek, dengan gaya dan sikap apa pun, mereka tidak akan marah dan tidak pula menunjukkan ekspresi marah ataupun cemburu. Akan tetapi, sekarang budaya atau kebiasaan tersebut tidak dilakukan lagi. Masyarakat datang memang hanya sekadar untuk melihat acara. Beberapa orang memang ada yang naik ke panggung, tetapi hanya sekedar untuk ikut menari atau menyanyi saja tanpa adanya tindakan nyawer maupun minum minuman keras. Hal ini karena sudah semakin tingginya kualitas pendidikan maupun pengetahuan masyarakat setempat. Selain itu juga karena semakin tingginya kesadaran masyarakat untuk beragama dan beribadah. Masyarakat sudah mampu membedakan antara perilaku yang sesuai atau sebaliknya justru menyimpang dari ajaran agama maupun norma setempat.

\section{Penutup}

\section{A. Simpulan}

Salah satu tradisi yang hingga saat ini masih dilestarikan oleh masyarakat Jawa tradisional adalah tradisi upacara bersih desa. Semakin maju dan berkembangnya zaman ternyata tidak menyurutkan semangat warga di Dusun Ganggong Desa Kiringan Kecamatan Takeran Kabupaten Magetan untuk melestarikan tradisi kejawen 
tersebut. Tradisi upacara bersih desa di daerah ini digelar setiap tahun sekali pada bulan Suro atau Muharram.

Dalam tradisi upacara bersih desa di Desa Kiringan, tidak hanya kaum laki-laki saja yang turut berpartisipasi, kaum perempuan juga ikut serta di dalamnya. Meskipun perempuan tidak berperan sebagai aktor utama, tetapi keberadaannya sangat penting. Tanpa keberadaan dari mereka tradisi tersebut tidak akan terlaksana. Dalam tradisi upacara tersebut, pelaku utama dalam persiapan maupun pelaksanaannya adalah laki-laki, sedangkan perempuan hanya sebagai pelaku kedua. Sebagai buktinya, yang berperan sebagai pemimpin dalam pelaksanaan upacara bersih desa tersebut adalah laki-laki. Perempuan hanya diberi tugas untuk mengerjakan peran sekunder yang berkaitan dengan tugas domestik seorang perempuan.

Dari hasil wawancara dengan beberapa informan diperoleh informasi mengenai peran dari kaum perempuan dalam persiapan dan pelaksanaan tradisi bersih desa tersebut. Peran dari kaum perempuan yaitu:

1. Pembuat Uborampe

Uborampe atau sajen
adalah simbol-simbol
perlengkapan yang diperlukan/
digunakan dalam acara
selamatan dalam tradisi upacara
bersih desa maupun dalam
tradisi lainnya. Uborampe ini
ada banyak macamnya, seperti
nasi kuning, ingkung, dan
kembang, dan lain sebagainya.
Dalam hal ini, para kaum
perempuan yang bertugas untuk
memenuhinya karena kaum
perempuan dianggap sebagai
seseorang yang lebih ahli atau
mampu dalam hal masak

memasak atau yang berkaitan dengan masalah dapur lainnya. Dalam upacara bersih desa di Desa Kiringan, uborampe yang digunakan adalah berupa nasi berkat dan kembang. Pada umumnya, yang selalu ada dalam nasi berkat tersebut adalah nasi kuning atau putih, ingkung, dan pisang.

2. Sebagai Tledhek

$$
\text { Peran lain dari }
$$

perempuan dalam tradisi upacara bersih desa adalah sebagai tledhek atau masyarakat Desa Kiringan biasa menyebutnya dengan kledhek. Dalam acara penutup upacara bersih desa biasanya selalu menampilkan acara hiburan berupa langen beksan. Langen beksan ini berupa kesenian Tayub atau Gambyong. Peran tledhek dalam acara hiburan ini adalah sebagai penari dan penyanyi (nyindhen).

Keberadaan kesenian Tayub ini merupakan pelengkap dalam tradisi bersih desa, jika seandainya tidak adapun juga tidak dipermasalahkan karena keberadaan kesenian Tayub adalah sebagai hiburan semata. Begitu juga dengan keberadaan tledhek, tledhek hanya sebatas sebagai hiburan bagi warga. Para pelaku atau pemain kesenian Tayub berasal dari daerah Nglembah (Dolopo), Ngawi, dan Magetan.

\section{B. Saran}

Setelah melakukan penelitian ini, sebagai peneliti dan insan akademis ada beberapa hal yang menjadi saran, yang diantaranya:

\section{Masyarakat Desa Kiringan}

Sebagai salah satu warisan budaya, tradisi upacara bersih desa semestinya dapat ditransformasikan kepada 
generasi berikutnya agar nantinya tradisi semacam ini dapat terjaga eksistensinya hingga masa yang akan datang.

\section{Perangkat Desa Kiringan}

$$
\text { Peneliti menaruh }
$$

harapan yang besar kepada seluruh pihak yang terlibat dalam pelaksanaan acara tradisi upacara bersih desa, khususnya perangkat Desa Kiringan untuk terus menjunjung tinggi nilai yang dianut oleh masyarakat serta menjaga warisan budaya lokal.

3. Dinas Kebudayaan Kabupaten Magetan

Peneliti menaruh harapan besar kepada segenap elemen yang berperan dalam promosi budaya, khususnya kepada pemerintah agar memfasilitasi pelaksanaan tradisi upacara bersih desa agar budaya tradisional ini dapat dipublikasikan secara lebih luas.

\section{Daftar Pustaka}

Emzir. 2011. Metode Penelitian Kualitatif Analisis Data. Jakarta: Rajawali

Jajat Burhanudin dan Oman Fathurahman. 2004. Tentang Perempuan Islam: Wacana dan Gerakan. Jakarta: Gramedia Pustaka Utama

Koentjaraningrat. 2009. Pengantar Ilmu Antropologi. Jakarta: Rineka Cipta

Mansour Fakih. 2007. Analisis Gender dan Transformasi Sosial. Yogyakarta: Pustaka Belajar

Milles, Matthew B. dan A. Michael Huberman. 1992. Analisis Data Kualitatif. Jakarta: UI Press

Suharsimi Arikunto. 1989. Prosedur Penelitian Suatu Pendekatan Praktek. Jakarta: PT. Bina Aksara Supardi. 2011. Dasar-Dasar Ilmu Sosial. Yogyakarta: Ombak

Sutopo, H. B. 2006. Metodologi Penelitian Kualitatif Dasar Teori dan Terapannya dalam Penelitian. Surakarta: Universitas Sebelas Maret. 